\title{
Science and Technology Parks: A study of value creation for park tenants
}

Alberto Albahari, Magnus Klofsten and J uan Carlos Rubio-Romero

The self-archived postprint version of this journal article is available at Linköping University Institutional Repository (DiVA):

http:/ / urn.kb.se/ resolve?urn=urn:nbn:se:liu:diva-146080

N.B.: When citing this work, cite the original publication.

The original publication is available at www.springerlink.com:

Albahari, A., Klofsten, M., Rubio-Romero, J . C., (2019), Science and Technology Parks: A study of value creation for park tenants, J ournal of Technology Transfer, 44(4), 1256-1272. https:// doi.org/ 10.1007/ s10961-018-9661-9

Open Access.

Original publication available at:

https:// doi.org/ 10.1007/ s10961-018-9661-9

Copyright: Springer Verlag (Germany)

http:/ / www.springerlink.com/ ?MUD=MP 


\title{
Science and Technology Parks: a study of value creation for park tenants
}

\author{
Alberto Albahari $^{1}$ (D) Magnus Klofsten $^{2}$ (D) Juan Carlos Rubio-Romero $^{1}$
}

Published online: 23 March 2018

(C) Springer Science+Business Media, LLC, part of Springer Nature 2018

\begin{abstract}
The literature on Science and Technology Parks (STPs) is growing rapidly and, despite the positive impact of STPs on firms found by many studies, it remains unclear how STPs create value for tenants. In this paper, we study the STP supply side through a case study in a Swedish region. We identify two components of the business support provided by parks: a configuration-oriented component, and a process-oriented component. The former refers to the static design of the business support, and the latter to the active, hands-on support provided by parks' management. Both components must be planned carefully in order to deliver value to tenants. We also discuss some implications for policy and managers.
\end{abstract}

Keywords Science and Technology Parks · Agglomerations · Added-value · Entrepreneurship · Innovation

JEL Classification $\quad \mathrm{O} 3 \cdot \mathrm{R} 1$

\section{Introduction}

Interest among policy-makers and academics in the effects of agglomerations and clusters on firm innovation has grown in recent years (McCann and Folta 2008). Science and

Alberto Albahari

alberto.albahari@uma.es

Magnus Klofsten

magnus.klofsten@liu.se

Juan Carlos Rubio-Romero

juro@uma.es

1 Department of Economics and Business Administration, Universidad de Málaga -School of Industrial Engineering, Campus de Teatinos, 29071 Málaga, Spain

2 Department of Management and Engineering, Helix Competence Centre and PIE, Linköping University, Linköping, Sweden 
Technology Parks (STPs) are a particular agglomeration subset which is policy-induced (Huang et al. 2012) and includes formal management teams (Colombo and Delmastro 2002). STPs have spread worldwide (Wainova 2009) and, in many countries, huge public investment is involved in their creation and growth (Link and Scott 2007; Albahari et al. 2013; Link and Yeong Yang 2017; Chen and Link 2017).

Several works (Hobbs et al. 2017a) analyse the added value and effects of an on-park location for firms. The majority of these studies focus on the demand side-STPs' tenants and entrepreneurs - to try to assess the impact on these firms of location in a STP and how entrepreneurs perceive the business support provided. Most analyses are aimed at understanding the importance of these organizations for tenant firms, measured as sales growth, increased profitability and employment (Lee and Yang 2000; Löfsten and Lindelöf 2002; Colombo and Delmastro 2002; Chen and Huang 2004; Hobbs et al. 2017b), the outputs of R\&D activities (Lindelöf and Löfsten 2003; Link and Scott 2003; Siegel et al. 2003; Squicciarini 2008; Yang et al. 2009) including innovation performance (Vásquez-Urriago et al. 2014; Albahari et al. 2016, 2017; Ramírez-Alesón and Fernández-Olmos 2017) and the capacity to establish formal and informal links with universities and other higher education institutions (Quintas et al. 1992; Vedovello 1997; Phillimore 1999; Link and Scott 2003; Fukugawa 2006; Malairaja and Zawdie 2008). The results of these studies are mixed. ${ }^{1}$

Despite ongoing debate and mixed evidence on the effectiveness of parks as tools to support technology-based firms, many studies find a positive impact of on-park location on firms' employment growth (Löfsten and Lindelöf 2002, 2003; Colombo and Delmastro 2002), sales growth (Löfsten and Lindelöf 2002, 2003), innovation output (VásquezUrriago et al. 2014; Squicciarini 2008, 2009; Huang et al. 2012; Chan et al. 2011; Siegel et al. 2003), R\&D productivity (Siegel et al. 2003; Yang et al. 2009) and interaction with universities (Fukugawa 2006; Löfsten and Lindelöf 2002, 2003; Colombo and Delmastro 2002; Vedovello 1997; Westhead and Storey 1995; Felsenstein 1994).

However, despite this large literature, in our view, one aspect of STPs that is poorly understood, is how STPs create value for their tenants. In particular, it is not clear whether the added value of on-park location derives mainly from the role of management and the active, hands-on support provided (i.e. business services to tenants) or from other structural characteristics (i.e. co-location with other firms, proximity of the park to a university), which are influenced only marginally by the presence of the park management team.

Many authors agree about the importance of park management in general, and the services it provides in particular. The existence of a formal park management team can provide a more secure basis for tenants' long-term development (Westhead and Batstone 1999) by helping young, innovative firms to solve the problems typically encountered (Monck et al. 1988), which include lack of managerial and commercial expertise, and lack of finance (Storey and Tether 1998). According to Cabral (1998), a successful park management team can offer firms managerial, marketing and financial expertise and skills, based on established and recognized experience, and leadership of the team by a high-profile person with good decision-making ability. Ratinho and Henriques (2010) agree on the importance of a high-profile management and provision of high quality services. According to these authors, the services provided are influential for determining the added value of an on-park location, to the extent that some STPs have been criticized for the non-provision of such services (Löfsten and Lindelöf 2002).

\footnotetext{
${ }^{1}$ For a review see, for instance, Albahari et al. (2010).
} 
However, there are also several authors who suggest that the added value of on-park location stems from other park characteristics not related to the services provided and influenced only partially by the park's management. For example, some find that tenants choose to be located in a park for reasons of prestige (Monck et al. 1988; Westhead and Batstone 1998; Bakouros et al. 2002; Ferguson and Olofsson 2004; Salvador 2011) and ease of establishing links with universities (Monck et al. 1988; Westhead and Batstone 1998). The paper by Albahari et al. (2016) tends to support the views of this group of authors. Albahari et al. find agglomeration effects related to STPs (the higher the number of tenants, the better the firms' innovation results) and that the services provided by park management have non-significant or even negative effects on firms' innovation results.

Thus, given this mixed evidence, it is not clear how STPs create value for their firms and, especially, whether the added value of park location stems from services provided to firms or from other park features. In this paper we contribute to the STP literature by trying to fill this research gap through a case study of two STPs located in the East Swedish Region. We describe their operation and how they configure their offers to create value for their tenants.

The rest of the paper is organized as follows: Sect. 2 describes the methodology used to perform the case study; Sect. 3 introduces the actors involved in the case study; Sect. 4 presents and discusses the findings; and Sect. 5 concludes, highlighting the implications of this study and suggesting further lines of research.

\section{Methodology}

In this paper, we study how two STPs in Östergötland County-an area of $3856 \mathrm{~km}^{2}$, in East Sweden, approximately $200 \mathrm{~km}$ southwest of Stockholm-design their offer in order to create value for tenants. The two STPs are the internationally-known Mjärdevi Science Park (MSP) in Linköping, which was founded in 1984, and the Norrköping Science Park (NOSP), which was founded in 1999.

The east Swedish innovation system has been studied in some detail (Benneworth et al. 2015; Hommen et al. 2006; Etzkowitz and Klofsten 2005; Klofsten et al. 1999; JonesEvans and Klofsten 1997), and the region is often cited as a case of successful collaboration between business, government and academic actors (Klofsten et al. 1999; Etzkowitz and Klofsten 2005; Svensson et al. 2012).

A case study methodology seems particularly suitable for this study since we are investigating 'how' questions, and the behaviours of the actors involved in the case study cannot be manipulated (Yin 2009).

We exploit several data sources. First, the scientific literature on Östergötland County's innovation system actors was studied; second, institutional documentation (web pages, press releases, articles in newspapers) was analysed; third, in-depth semistructured interviews with each relevant stakeholder were conducted with people in key supply-side positions. Interviewees included the CEOs of MSP and NOSP, the CEO of the LEAD (LiU Entrepreneurship and Development business incubator), the heads of the Linköping University (LiU) Innovation Office and Centre for Innovation and Entrepreneurship (CIE), the head of the Department for Trade and Industry in Norrköping Municipality, the Director of Entrepreneurship and Employability in East Sweden Region, two politicians from the Linköping and Norrköping municipalities and one from the Östergötland County Administrative Board. A total of ten in-depth interviews 


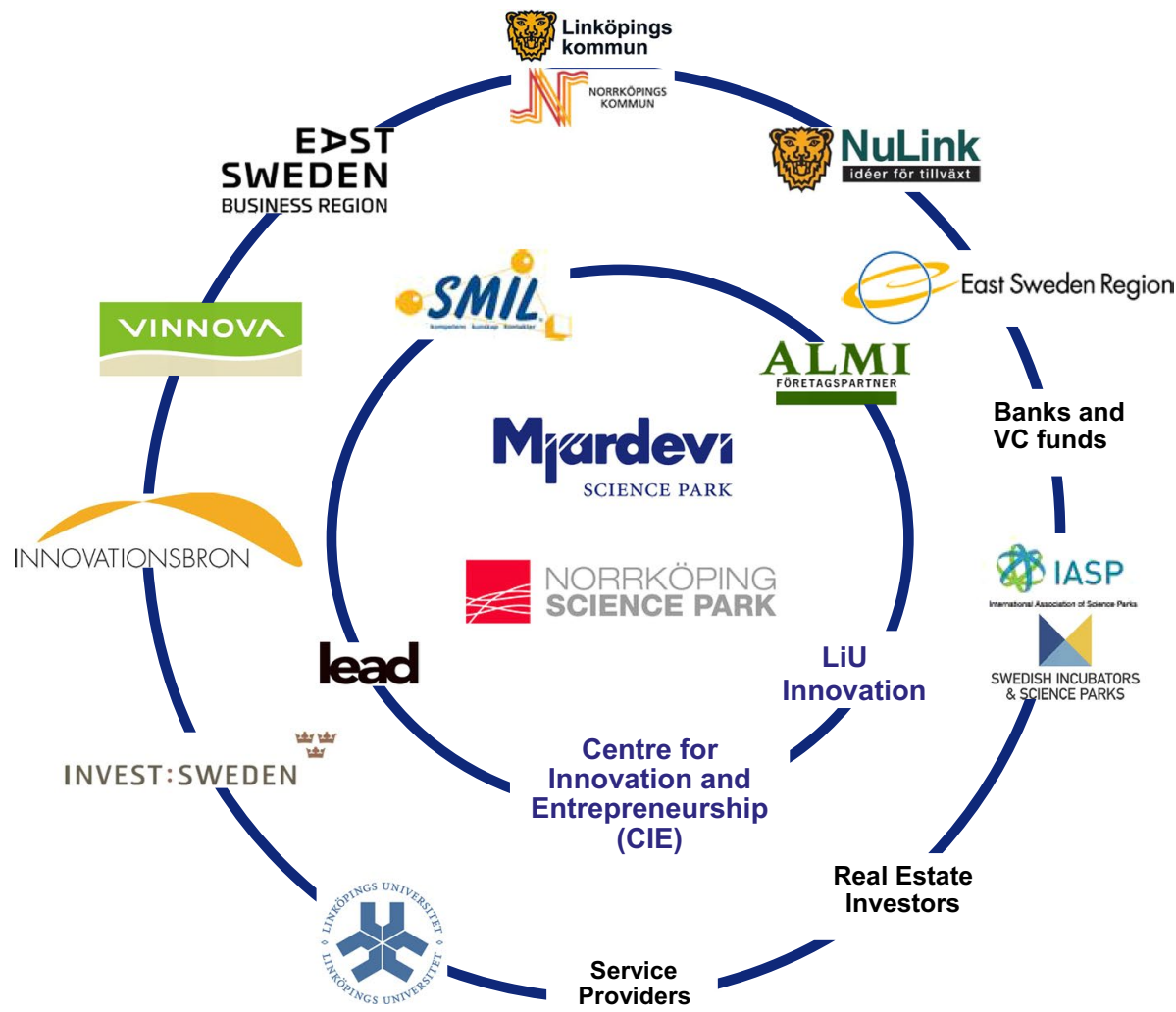

Fig. 1 MSP's and NOSP's network. Adapted from Sten Gunnar Johansson, CEO of MSP

(each lasting between 60 and $90 \mathrm{~min}$ ) was conducted during the period January-February 2011. The interviews were aimed at understanding what different park stakeholders do, how parks configure their offer, involvement and functions of the different actors within the regional system, and the formal and informal links between their organization and the STPs.

In some cases, we arranged second meetings or communicated by email with the interviewees. At least one field visit was made to each stakeholder.

In Sect. 3, we introduce the different regional innovation system actors related to MSP and NOSP.

\section{The Östergötland County regional innovation ecosystem}

The two STPs in Östergötland County are integrated in a regional ecosystem of actors from the private sector, LiU and different levels of local government. In Fig. 1, the inner circle includes those actors with the strongest and most frequent relations with the parks.

The components of this regional system at the time of the case study are described below. 


\subsection{Science Parks}

\subsubsection{Mjärdevi Science Park}

MSP has been the subject of many studies and papers (Hommen et al. 2006; Cadorin et al. 2017) and is considered one of the most successful STPs in Europe. It was founded in 1984 and grew rapidly and currently occupies an area of 70 ha alongside LiU's Valla Campus, and today hosts some 350 companies, which employ over 6500 people. Although many of MSP's tenant firms are involved with Information Technology (IT) related goods (e.g. electronics, telecommunication and signal processing, software and systems development, image processing), it is a multi-purpose STP which includes innovative firms from various sectors. The company that manages the Park, Mjärdevi Science Park AB, is owned by the Municipality of Linköping and has six fulltime employees.

\subsubsection{Norrköping Science Park}

NOSP was founded in 1999 and in 2017 hosted some 130 companies and 700 employees. The park is located in the city of Norrköping and has no specific geographical delimitation, which differentiates it from most other STPs worldwide, which have a specific perimeter. Firms located in the city which meet NOSP's admission criteria, can decide to join the park and become a 'park company'. Like MSP, NOSP is a multi-purpose STP specialized in some profile areas related to the research conducted on LiU's Norrköping campus, including visualization, printed electronics and interactive services.

NOSP is owned by the Norrköping Science Park Foundation, whose shareholders include the Municipality of Norrköping, LiU and the private sector. The park is managed by Norrköping Science Park $A B$, is owned by the foundation and employs seven full-time employees.

\section{2 $\mathrm{LiU}$ and related actors}

\subsubsection{Linköping University (LiU)}

LiU is a major Swedish university, with a student population of 27,000, and 4000 employees. It includes 4 faculties (Arts and Science, Medicine and Health Sciences, Education Sciences, and Science and Engineering) and 14 departments.

Relations between the two STPs and LiU are not restricted to the immediate neighbourhood (MSP and NOSP are located alongside LiU campuses). LiU is strategically important to both MSP and NOSP since both parks are specialized in profile areas in which their neighbouring campuses excel, and many park activities involve professionals from LiU. In addition to expertise, LiU provides park tenancies since university spin-offs are encouraged to locate in a park.

The most evident links between the two STPs and LiU are that both enjoy cooperation with CIE, the university's business incubator, LEAD, and LiU Innovation, LiU's technology transfer office. Informal contacts between the managers of firms in the two STPs and professors and researchers at LiU are not uncommon. 


\subsubsection{Centre for Innovation and Entrepreneurship}

CIE is an autonomous unit in Linköping University that was established in 1994. CIEs mission is to facilitate integration between stimulation activities for technology-based firms and teaching and research in technology-based entrepreneurship in LiU (Jones-Evans 2007). CIE works to promote growth and development of technology-based firms through entrepreneurship and development programmes for new businesses and established firms, networking and other activities. Due to its success, this experience has been transferred to other regions in Sweden (Klofsten et al. 2010).

CIE has established relationships with MSP and NOSP based on mutual interests: CIE's activities constitute a part of the management offer in the two STPs, and more than 130 new firms established by former participants in CIE's entrepreneurship programmes have chosen an on-park location. At the same time, both STPs encourage the participation of park firms in CIE's activities.

\subsubsection{LEAD: the business incubator}

LEAD was set up in 2007 by merging the business incubators in Linköping and Norrköping. It is owned by LiU and has branches in MSP and NOSP. LEAD offers a 36-month incubation and acceleration programme and assists park companies by providing experienced business coaches. More than 120 companies have been incubated successfully by LEAD (2017).

\subsubsection{LiU Innovation}

Liu Innovation, LiU's technology transfer office, provides pre-incubation support for students, scientists and researchers who want to commercialize their ideas, and advises them about the development of their business ideas.

\subsection{Industry and private actors}

\subsubsection{Small Business Development Foundation (SMIL)}

The cluster initiative SMIL was set up in 1984 by a group of entrepreneurs to enhance their business skills (Etzkowitz and Klofsten 2005). Its members are technology- and knowledge-based firms in the region. SMIL has expanded and now hosts breakfast meetings where lecturers from LiU's management department and representatives of other organisations, give presentations on subjects of interest, and provides well-defined sets of stimulation activities tailored to members' needs (Jones-Evans and Klofsten 1997; Laur et al. 2012). SMIL collaborates with CIE on many activities and is a good example of industryacademia collaboration.

\subsubsection{Other private actors}

The management of MSP and NOSP have established extensive networks with other private actors important to the parks and their firms (Svensson et al. 2012). They include real estate investors (MSP and NOSP do not own land), banks, venture capital funds and other investors. 


\subsection{Government bodies and government-owned companies}

\subsubsection{Municipalities}

The Municipalities of Linköping and Norrköping are directly involved on the supplysides of MSP and NOSP. The Municipality of Linköping owns MSP and provides Kr6 million (approximately $€ 700,000)$ per year for MSP's activities. Norrköping Municipality is a member of the Norrköping Science Park Foundation which owns NOSP's management company (Svensson et al. 2012).

\subsubsection{ALMI}

ALMI (Almi Företagspartner AB) is a public company, owned by the Swedish government and the parent company of a group consisting of 16 regional subsidiaries. Regional subsidiaries are owned $51 \%$ by the state and $49 \%$ by local governments (East Sweden Region). Its board includes politicians, local business representatives and organizations linked to the business world. Its aim is to "promote the development of competitive small and medium-sized businesses as well as to stimulate new enterprise with the aim of creating growth and innovation in Swedish business life. Its activity covers the whole process from idea to profitable business" (ALMI 2013). In addition to providing consultancy services, ALMI participates in venture capital activity, providing funds, both loans and equity, especially at the early stages of firm development. Both parks collaborate actively with ALMI.

\subsubsection{Nulink}

Nulink was a company that was owned by the Municipality of Linköping. It was set up in 2007 to promote business development in the city. Nulink's mission was to advise on, support and inspire entrepreneurial activity, creation of new business, and support for businesses in the Linköping region. It provided support to both newly established companies and start-ups. It organized courses, networking lunches, inspirational seminars and conferences, in collaboration with other actors, with the aim of facilitating the process of development of new business ideas and creation of new businesses. A large part of the support provided by Nulink was focused on practical issues such as identifying local businessmen and premises to help new companies to get established or to help existing companies in Linköping to expand (Nulink 2013). Nulink ceased operations in 2017 and has been replaced by Business and Growth (Näringsliv och Tillväx in Swedish) a unit of the Linköping municipality.

\subsubsection{East Sweden Region}

The East Sweden Region comprise of representatives from the 13 municipalities and the county council. Its goal is to promote development, growth and competitiveness in the region. 


\subsubsection{Vinnova}

Vinnova is the Sweden Innovation Agency. It is controlled by the Ministry of Enterprise and Innovation and aims to contribute to sustainable growth and increase the competitiveness of Swedish researchers and companies. Vinnova invests some $€ 300$ million per year to foster innovation in Swedish companies and promotes sustainable growth in Sweden by funding needs-driven R\&D into effective innovation systems (VINNOVA 2018).

\subsubsection{Innovationsbron}

The Innovationsbron or Innovation Bridge, prior to its merger in 2013 with ALMI AB, was a national agency providing early-stage funding to new, potentially high growth companies. Its aim was to promote early stage entrepreneurship, mainly through seed capital, to generate businesses from ideas. It was owned $84 \%$ by the state and $16 \%$ by private industry (Innovationsbron 2011).

\subsubsection{Invest Sweden}

Invest Sweden was a national government agency whose main aim was to attract investment to Sweden by helping foreign companies to do business there. It offered practical information on how to set up and run a business in Sweden, gave information on Swedish markets and facilitated contact with the Swedish authorities. The collaboration with MSP and NOSP was important for delivering the 'soft landing' programmes used by both parks to attract foreign firms. In 2013, Invest Sweden merged with the Swedish Trade Council (Exportrådet, in Swedish) to create Business Sweden, a public-private partnership created with the aim of attracting foreign investment by helping foreign companies in their business operations in Sweden.

\subsection{Other actors}

\subsubsection{East Sweden Business Region}

East Sweden Business Region (formerly Growlink) is a networking platform that includes many regional innovation system stakeholders-both STPs, LiU, CIE, SMIL, LEAD, ALMI, Innovationsbron, East Sweden Region and, as minor stakeholders, the Östergötland County Administrative Board and the Municipalities of Linköping and Norrköping. East Sweden Business Region supports the establishment and growth of knowledge intensive companies (Johansson 2009).

\subsubsection{International Association of Science and Technology Parks (IASP) and Swedish Incubators and Science Parks Association (SISP)}

The International Association of Science and Technology Parks (IASP) has been operating since 1984 and currently connects 375 members in 77 countries, which represents 142,000 
companies operating within the global knowledge economy. The Swedish Incubators and Science Parks Association (SISP) has 66 members (33 STPs and 43 incubators) hosting some 5000 companies and is a member of IASP.

At the time of the interviews MSP and NOSP were full members of both IASP and SISP. $^{2}$

\section{Findings and discussion}

Analysis of the offers of the two STPs identifies two main components: static or blueprint design of the support provided to customers, and active hands-on support provided to park tenants by STP management, through various mechanisms and providers. Following Autio and Klofsten (1998) we describe these types of business support as respectively configuration-oriented and process-oriented.

An important difference between the two parks analysed is that while NSP is a traditional real-estate based STP, NOSP can be considered a 'virtual' STP (Durão et al. 2005) since it has no fixed perimeter and all the innovative firms located in the city of Norrköping can apply to join the park. However, we found no major differences between the designs of the offers provided by these two STPs.

Below, we shed some light on how parks create added value for tenants through these two types of business support and how they deal with possible problems related to the delivery of added value.

\subsection{Configuration-oriented business support}

Configuration-oriented support typically is designed during the planning stages of a STP. The interviews allowed us to identify three main aims of the STP supply-side when designing this component of its offer: (1) amplifying agglomeration effects; (2) increasing the availability of venture capital funding; (3) ensuring proximity to a major university.

\subsubsection{Amplifying agglomeration effects}

Agglomeration effects are the various types of externalities promoted by spatial co-location (Audretsch 1998).

Both STP CEOs agreed about the importance of clear admissions criteria to enhance agglomeration effects. The CEOs believed that the possibility to select prospective tenants strengthened the parks' identities. MSP and NOSP include new firms based on the level of their innovativeness and knowledge intensity, and the viability and growth potential of their business. Both parks prioritize firms related to their profile areas, which coincide with those of the respective local LiU campuses. For MSP these are electronics, telecommunication and signal processing, software and systems development, and image processing; for NOSP they are visualization, printed electronics and interactive services.

A notable difference in the admissions policies of the two parks is that MSP does not allow production activities and facilities. Although this can be a source of conflict with real estate investors, whose main interest is letting all the available spaces, it contributes

${ }^{2}$ Currently, NOSP is a full member only of SISP. 
to a strong park identity and demonstrates a clear orientation to innovation, entrepreneurship and R\&D, rather than production activities. In the case of NOSP, however, any firm located in Norrköping can apply to join the park, regardless of involvement or not in production activities. Neither of the two STPs owns the land on which they are located, which requires some mediation with real estate developers, especially for MSP, which has a formal perimeter.

Some studies demonstrate the benefit of increasing the number of firms in agglomerations (Albahari et al. 2016; McCann and Folta 2011; Beaudry and Swann 2009). For park managers, it is paramount to generate a flow of prospective tenants and to attract new innovative firms to the facility. Thus, both CEOs pointed to the importance of providing attractive infrastructure that is appropriate to tenants' needs. MSP and NOSP provide flexible spaces for start-ups via the LEAD incubator, and guarantee availability of appropriate spaces for non-incubated firms. Tenants, for their part, expect a certain availability of the basic services provided in city neighbourhoods (e.g. restaurants and bars, nursery facilities, ATM machines, supermarket, post office); these are installed in MSP by external providers and, given NOSP's location in Norrköping city, are available locally.

\subsubsection{Availability of venture capital funds}

Financing is a major issue for all businesses and, especially, technology-based start-ups and firms perceived as particularly risky (Storey and Tether 1998).

The parks use two main mechanisms to cope with funding issues. First, they integrate in their network venture capital organizations and providers of seed capital, both public and private (e.g. ALMI AB, Vinnova, Innovationsbron, banks and venture capitalists); second, they 'filter' the companies, by strict application of the park admissions criteria, and ensuring that only knowledge-based start-ups and firms with high growth potential join the parks. This filtering applies also to the LEAD incubator, which accepts only start-ups with high business potential. In the view of the park managers, this filtering makes on-park companies more attractive to investors than other innovative start-ups, because they are perceived as being less risky.

\subsubsection{Proximity to the university}

Both MSP and NOSP are located in the immediate vicinity of LiU campuses, respectively Valla Campus and Norrköping Campus. Although proximity is not a sufficient condition for establishing links with universities, our interviewees believe that greater distance from the university would hamper the possibility of technology and knowledge transfer. The relative closeness of university facilities facilitates bidirectional communication and flows of people and information between LiU and park tenants. According to the parks' CEOs, the decisions to locate proximate to the university and to specialize in the research areas of the neighbouring campuses, are clear signals of the strategic importance of LiU to the STPs. In particular, specialization in the same research areas is intended to signal a preferential location for university spin-offs and to enhance other types of proximity, such as organizational, cultural and technological proximity (Knoben and Oerlemans 2006), which are important for the innovation process (Boschma 2005).

Table 1 summarizes the aims and practice actions undertaken by park management when designing configuration-oriented business support for tenants. 
Table 1 Configuration-oriented business support

\begin{tabular}{|c|c|c|}
\hline & Aim & How? \\
\hline \multirow[t]{2}{*}{$\begin{array}{l}\text { Amplification of agglomeration } \\
\text { effect }\end{array}$} & Build a strong identity & $\begin{array}{l}\text { Selecting prospective tenants } \\
\text { Strictly applying admission criteria }\end{array}$ \\
\hline & Increase number of firms & $\begin{array}{l}\text { Attracting university spin-offs } \\
\text { Offering attractive infrastructures }\end{array}$ \\
\hline Availability of VC funds & Make funds available & $\begin{array}{l}\text { Reducing perceived risk by investors } \\
\text { Networking with VCs }\end{array}$ \\
\hline Proximity to university & $\begin{array}{l}\text { Facilitate technology transfer and } \\
\text { knowledge spillovers }\end{array}$ & $\begin{array}{l}\text { Geographical proximity } \\
\text { Specialization in same expertise areas }\end{array}$ \\
\hline
\end{tabular}

\subsection{Process-oriented business support}

Process-oriented business support is related to the design of a wide range of activities and services, which supply-side managers intend will be tailored to customers' needs.

The services provided within the two parks are similar and fall into three broad categories: incubation, training and networking.

\subsubsection{Incubation}

Both parks encourage start-ups to go through the LEAD incubation process; however, this is not the only means available to firms to take advantage of a controlled environment. Firms that fail to meet LEAD's admissions criteria or whose entrepreneurs prefer not to be incubated, can participate in MSP's 'kick-start' programme or NOSP's 'start-up' programme. Both programmes are designed to assist firms during their first 6 months through the provision of external consultancy, access to lawyers, marketing experts and business coaches, and the possibility to rent space at a reasonable price.

\subsubsection{Training}

Both parks offer training in the form of entrepreneurship programmes provided by CIE in collaboration with SMIL, for entrepreneurs and firm managers of companies at different stages of development. The training includes programmes addressed to firms at the pre-incubation, incubation and post incubation stages, and are designed to help firms develop their business ideas and reduce the perceived risk for investors. Most programmes include a small number of individual firm classroom and coaching sessions.

Business coaching is considered by park management to be an important feature of their offer. It is a fundamental part of all the courses and programmes provided and is delivered in personalized sessions by CIE, SMIL and external experts. Incubated firms receive coaching on a continuing basis from LEAD business coaches.

Other courses are provided to STP tenants with input from external experts (e.g. 'Marketing and Sales' and the 'kick-start' courses at MSP, and the 'start-up' course at NOSP). 
Table 2 Reducing potential obstacles to effective business support delivery

\begin{tabular}{ll}
\hline Aim & How? \\
\hline Meet entrepreneurs' real needs & $\begin{array}{l}\text { Personalised support according to the stage } \\
\text { of development (pre-, during, and post- } \\
\text { incubation) }\end{array}$ \\
& $\begin{array}{l}\text { Individual coaching sessions } \\
\text { Flexibles spaces }\end{array}$ \\
Motivate entrepreneurs & $\begin{array}{l}\text { Acknowledged experts } \\
\text { Appropriate activities schedule }\end{array}$ \\
& $\begin{array}{l}\text { Fee policy/rent prices } \\
\text { Communicate value }\end{array}$ \\
& $\begin{array}{l}\text { Promoting services provided } \\
\text { Stressing expected results of support activities }\end{array}$ \\
\hline
\end{tabular}

\subsubsection{Networking}

Networking and collaboration with external actors are strategic tools employed by both STPs in their business models. Park managers consider networking to be pivotal to development of both on-park firms and the STPs. Networking allows companies to access to various kinds of support (including financial) and competences.

The interviews with park managers demonstrated the importance given to the integration in their offer of actors from industry, academia and other institutions, which is in line with triple helix theory (Etzkowitz and Leydesdorff 1997) and a common trait of many successful STPs (Howard and Link 2017). The existence and integration of these actors is crucial for shaping the STPs' offers since they rely heavily on outsourcing for their services provision. The STP management plays an important part in building and nurturing this actor network and selecting business partners.

Collaboration between parks and external actors is not necessarily formal. When we asked interviewees about the type of collaboration between their organization and the STP, we found that collaboration was mainly informal. Thus, it is not surprising that this pattern of collaboration is based on mutually beneficial relations and arrangements.

When networks span national borders, tenants have the opportunity to increase their international visibility. MSP and NOSP are members of SISP and IASP and participate also in extensive informal networks that allow park managers to provide tenants with information on foreign markets, international contacts and expansion opportunities, and advice on internationalization strategies.

\subsection{Delivering effective business support}

Supply-side managers are aware that there are several potential obstacles that might reduce the effectiveness of the business support provided. These include cultural barriers to networking, negative attitude to learning activities, lack of interest and motivation, lack of time and negative perception of the utility of the services provided. To tackle these potential misalignments between what the parks offer and what tenants expect, supply-side managers must ensure appropriate design of both configuration- and process-oriented support (Table 2). 
The park managers interviewed tended to assign greater importance to process-oriented support. This is likely because a large part of their time is devoted to the design, organization and supervision of the activities related to process-oriented support, whereas configuration-oriented support is confined mostly to the early stages of STP development. However, in our view, the effects of the configuration-oriented support should not be underestimated for two reasons: on the one hand, there is a great deal of evidence of the importance for firms of agglomeration effects (Gordon and McCann 2005), availability of venture capital (Kortum and Lerner 2001) and proximity to a university (Laursen et al. 2011) and, on the other hand, because poorly designed configuration-oriented support could result in less effective process-oriented support.

Meeting managers' and entrepreneurs' real needs is believed per se to be the best way to avoid problems related to the delivery of business support activities and makes clear their added value. According to park CEOs, in order to meet firms' real needs, personalized support that takes account of the characteristics of firms, is required. To this end, MSP and NOSP provide different types of support to firms according to their stage of development, such as entrepreneurs with yet undeveloped business ideas (pre-incubation stage), firms at early stage of development (incubation stage), firms that have graduated recently from the incubation process (post-incubation stage) and established firms. Within this scheme (e.g. entrepreneurship courses), content varies according to participant type. Individual coaching sessions are an example of this personalized support.

Effective communication between park management and tenants is considered particularly important for the efficient delivery of business support. In particular, park CEOs agree about the importance of promoting the services provided and stressing the expected results of support activities. Impressing on entrepreneurs the utility of different support schemes motivates them to participate in park activities and reduces the cultural barriers related to networking and sharing of experience.

Some entrepreneurs will be reluctant to apply for services provided by people with no practical business experience and MSP and NOSP rely on highly-skilled and acknowledged experts for the delivery of their entrepreneurship and management programmes, coaching and mentoring, and business advice and other services. Experts include professors at $\mathrm{LiU}$ with strong business backgrounds and recognized experience. The collaboration between the STPs, CIE and SMIL is believed essential for achieving the desired mix of business and teaching competences.

In addition, the specific design of each activity is important to reduce problems that might arise in the delivery of business support. In particular, scheduling needs to be appropriate to overcome the chronic lack of time which prevents entrepreneurs from attending courses and other activities. For example, MSP's Entrepreneurship and New Business Development Programme provided by CIE and SMIL, includes ten classroom days which are spread over a period of 4-6 months while its Market and Sales Course is a weekly (for 5 months), 3-h evening session.

MSP and NOSP tenants do not have to pay their respective park management for park location; they pay only for the services they access. This is part of the 'tailoring' to firms' needs. However, for MSP firms, on-park location is more expensive because of the higher rent (payable to the landowner) than location in the centre of Linköping; thus, only firms that recognize the benefits of an on-park location will find it favourable. 


\section{Concluding remarks}

The aim of this paper was to shed light on how STPs create value for their tenants. We conducted a case study of two STPs, the Mjärdevi Science Park (MSP) and the Norrköping Science Park (NOSP), in the East Sweden Region.

We identified two main components of the STPs' offers: a configuration-oriented component comprising a static business support design, and a process-oriented component related to the services and activities offered to tenants (c.f. Autio and Klofsten 1998). The former includes provision of appropriate infrastructure, building a strong identity for the STP, availability of venture capital funding and proximity to a major university; the latter includes incubation, training and networking activities for firms. Both components must be planned carefully to deliver value to tenants.

This study has implications for park managers, firm managers and policymakers.

For park managers it suggests the need for a comprehensive view when designing and implementing the park's offer, including both configuration- and process-oriented support. Being efficiently integrated into a triple-helix configured network of partners is crucial for shaping an STP's offer. Both creating value for tenants and communicating value to tenants are important for effectively value delivery.

For tenants and prospective tenants, this research should be informative for firm managers about the added value of on-park location. In particular, firm managers should be aware of the two components of the support provided by parks.

Finally, our work helps policymakers to better understand STPs dynamics as a business support tool. As a geographically bounded initiative, STPs are often compared to spontaneous agglomerations (Huang et al. 2012). Even if performing a compared cost-benefit analysis is out of the aims of this paper, our study suggests that STPs offer idiosyncratic support that is not available in spontaneous agglomerations. While it is true that services can be bought from consulting firms, park management play an important role in enhancing the agglomeration effects, providing an incubation environment for start-ups, fostering networking and contacts with universities and venture capitalists, and increasing the international visibility of tenant firms. Furthermore, since STPs are often publicly funded, they enjoy an institutional legitimacy that is not found in spontaneous agglomeration.

In future research, it would be interesting to investigate the demand-side of STPs, to assess how the support provided is perceived. Based on the data available on firms, it would be useful to assess how different managerial practices affect firm performance and how relations between parks and external actors affect tenants' performance. Finally, this study could be replicated in regions and countries characterized by weaker innovation systems, which would add interesting insights into how STPs work and would create value for these environments.

Acknowledgements The authors want to thank all the interviewees, especially Sten Gunnar Johansson, Åke Rolf and Christian Berger for their precious time. A previous version of this paper has been presented to the Triple Helix IX International Conference at Stanford University in 2011. The authors thank the participants to the conference for their useful comments. Alberto Albahari wants to acknowledge funding from the University of Malaga for carrying out the research staying in Sweden and for attending the conference.

Funding Funding was provided by Universidad de Málaga (Grant No. C.3.; A.1. III Plan Propio de Investigación de la Universidad de Málaga). 


\section{References}

Albahari, A., Barge-Gil, A., Pérez-Canto, S., \& Modrego, A. (2016). The influence of Science and Technology Park characteristics on firms' innovation results. Papers in Regional Science. https://doi. org/10.1111/pirs.12253.

Albahari, A., Catalano, G., \& Landoni, P. (2013). Evaluation of national Science Park systems: A theoretical framework and its application to the Italian and Spanish systems. Technology Analysis \& Strategic Management, 25(5), 599-614.

Albahari, A., Pérez-Canto, S., Barge-Gil, A., \& Modrego, A. (2017). Technology Parks versus Science Parks: Does the university make the difference? Technological Forecasting and Social Change, 116, 13-28.

Albahari, A., Pérez-Canto, S., \& Landoni, P. (2010). Science and Technology Parks impacts on tenant organisations: A review of literature. MPRA Paper No. 41914. University Library of Munich, Germany.

ALMI. (2013). ALMI AB. Available at http://www.almi.se. Accessed 10 June 2013.

Audretsch, B. (1998). Agglomeration and the location of innovative activity. Oxford Review of Economic Policy, 14(2), 18-29.

Autio, E., \& Klofsten, M. (1998). A comparative study of two European business incubators. Journal of Small Business Management, 36(1), 30-43.

Bakouros, Y. L., Mardas, D. C., \& Varsakelis, N. C. (2002). Science park, a high tech fantasy? An analysis of the science parks of Greece. Technovation, 22(2), 123-128.

Beaudry, C., \& Swann, P. (2009). Firm growth in industrial clusters of the United Kingdom. Small Business Economics, 32(4), 409-424.

Benneworth, P., de Boer, H., \& Jongbloed, B. (2015). Between good intentions and urgent stakeholder pressures: Institutionalizing the universities' third mission in the Swedish context. European Journal of Higher Education, 5(3), 280-296.

Boschma, R. (2005). Proximity and innovation: A critical assessment. Regional Studies, 39(1), 61-74.

Cabral, R. (1998). Refining the Cabral-Dahab science park management paradigm. International Journal of Technology Management, 16(8), 813-818.

Cadorin, E., Johansson, S. G., \& Klofsten, M. (2017). Future developments for science parks: Attracting and developing talent. Industry and Higher Education, 31(3), 156-167.

Chan, K. Y. A., Oerlemans, L. A., \& Pretorius, M. W. (2011). Innovation outcomes of South African new technology-based firms: A contribution to the debate on the performance of science park firms. South African Journal of Economic and Management Sciences, 14(4), 361-378.

Chen, C. J., \& Huang, C. C. (2004). A multiple criteria evaluation of high-tech industries for the sciencebased industrial park in Taiwan. Information \& Management, 41(7), 839-851.

Chen, C., \& Link, A. N. (2017). Employment in China's hi-tech zones. International Entrepreneurship and Management Journal. https://doi.org/10.1007/s11365-017-0486-z.

Colombo, M. G., \& Delmastro, M. (2002). How effective are technology incubators? Evidence from Italy. Research Policy, 31(7), 1103-1122.

Durão, D., Sarmento, M., Varela, V., \& Maltez, L. (2005). Virtual and real-estate science and technology parks: A case study of Taguspark. Technovation, 25(3), 237-244.

Etzkowitz, H., \& Klofsten, M. (2005). The innovative region: Toward a theory of knowledge-based regional development. R\&D Management, 35(3), 243-255.

Etzkowitz, H., \& Leydesdorff, L. (1997). Universities and the global knowledge economy: A triple helix of university-industry-government relations. London: Pinter.

Felsenstein, D. (1994). University-related science parks-Seedbeds or enclaves of innovation. Technovation, 14(2), 93-110.

Ferguson, R., \& Olofsson, C. (2004). Science parks and the development of NTBFs-Location, survival and growth. The Journal of Technology Transfer, 29(1), 5-17.

Fukugawa, N. (2006). Science parks in Japan and their value-added contributions to new technology-based firms. International Journal of Industrial Organization, 24(2), 381-400.

Gordon, I. R., \& Mccann, P. (2005). Innovation, agglomeration, and regional development. Journal of Economic Geography, 5(5), 523-543.

Hobbs, K. G., Link, A. N., \& Scott, J. T. (2017a). Science and technology parks: An annotated and analytical literature review. The Journal of Technology Transfer, 42(4), 957-976.

Hobbs, K. G., Link, A. N., \& Scott, J. T. (2017b). The growth of US science and technology parks: Does proximity to a university matter? Annals of Regional Science, 59(2), 495-511.

Hommen, L., Doloreux, D., \& Larsson, E. (2006). Emergence and growth of Mjardevi Science Park in Linkoping, Sweden. European Planning Studies, 14(10), 1331-1361. 
Howard, E. S., \& Link, A. N. (2017). An Oasis of knowledge: The early history of gateway university research park. Journal of the Knowledge Economy. https://doi.org/10.1007/s13132-017-0513-X.

Huang, K. F., Yu, C. M. J., \& Seetoo, D. H. (2012). Firm innovation in policy-driven parks and spontaneous clusters: The smaller firm the better? The Journal of Technology Transfer, 37(5), 715-731.

Innovationsbron. (2011). Available at http://www.innovationsbron.se/en. Accessed 10 June 2011.

Johansson, S. G. (2009). New challanges meet old experience-Networking as astrategic tool. Working paper 2009-08-20/MSP. Linköping: Mjärdevi Science Park.

Jones-Evans, D. (2007). Entrepreneurship environment and policies: Exploiting the science and technology base in the region of Halle. OECD LEED local entrepreneurship series. Paris: OECD.

Jones-Evans, D., \& Klofsten, M. (1997). Universities and local economic development: The case of Linköping. European Planning Studies, 5(1), 77-93.

Klofsten, M., Heydebreck, P., \& Jones-Evans, D. (2010). Transferring good practice beyond organizational borders: Lessons from transferring an entrepreneurship programme. Regional Studies, 44(6), 791-799.

Klofsten, M., Jones-Evans, D., \& Schärberg, C. (1999). Growing the Linköping technopole-A longitudinal study of triple helix development in Sweden. Journal of Technology Transfer, 24(2-3), 125-138.

Knoben, J., \& Oerlemans, L. A. G. (2006). Proximity and inter-organizational collaboration: A literature review. International Journal of Management Reviews, 8(2), 71-89.

Kortum, S., \& Lerner, J. (2001). Does venture capital spur innovation? In G. D. Libecap (Ed.), Entrepreneurial inputs and outcomes: New studies of entrepreneurship in the United States (pp. 1-44). Bingley: Emerald Group Publishing Limited.

Laur, I., Klofsten, M., \& Bienkowska, D. (2012). Catching regional development dreams: A study of cluster initiatives as intermediaries. European Planning Studies, 20(11), 1909-1921.

Laursen, K., Reichstein, T., \& Salter, A. (2011). Exploring the effect of geographical proximity and university quality on university-industry collaboration in the United Kingdom. Regional Studies, 45(4), 507-523.

LEAD. (2017). LiU entrepreneurship and development. Available at http://www.lead.se/en. Accessed 14 December 2017.

Lee, W. H., \& Yang, W. T. (2000). The cradle of Taiwan high technology industry development-Hsinchu Science Park (HSP). Technovation, 20(1), 55-59.

Lindelöf, P., \& Löfsten, H. (2003). Science park location and new technology-based firms in SwedenImplications for strategy and performance. Small Business Economics, 20(3), 245-258.

Link, A. N., \& Scott, J. T. (2003). US science parks: The diffusion of an innovation and its effects on the academic missions of universities. International Journal of Industrial Organization, 21(9), 1323-1356.

Link, A. N., \& Scott, J. T. (2007). The economics of university research parks. Oxford Review of Economic Policy, 23(4), 661-674.

Link, A. N., \& Yeong Yang, U. (2017). On the growth of Korean technoparks. International Entrepreneurship and Management Journal. https://doi.org/10.1007/s11365-017-0459-2.

Löfsten, H., \& Lindelöf, P. (2002). Science Parks and the growth of new technology-based firms-Academic-industry links, innovation and markets. Research Policy, 31(6), 859-876.

Löfsten, H., \& Lindelöf, P. (2003). Determinants for an entrepreneurial milieu: Science Parks and business policy in growing firms. Technovation, 23(1), 51-64.

Malairaja, C., \& Zawdie, G. (2008). Science parks and university-industry collaboration in Malaysia. Technology Analysis \& Strategic Management, 20(6), 727-739.

McCann, B. T., \& Folta, T. B. (2008). Location matters: Where we have been and where we might go in agglomeration research. Journal of Management, 34(3), 532-565.

McCann, B. T., \& Folta, T. B. (2011). Performance differentials within geographic clusters. Journal of Business Venturing, 26(1), 104-123.

Monck, C. S. P., Porter, R. B., Quintas, P., Storey, D., \& Wynarczyk, P. (1988). Science parks and the growth of high-technology firms. London: Croom Helm.

NULINK. (2013). Available at http://www.nulink.se. Accessed 10 June 2013.

Phillimore, J. (1999). Beyond the linear view of innovation in science park evaluation-An analysis of Western Australian Technology Park. Technovation, 19(11), 673-680.

Quintas, P., Wield, D., \& Massey, D. (1992). Academic-industry links and innovation-Questioning the science park model. Technovation, 12(3), 161-175.

Ramírez-Alesón, M., \& Fernández-Olmos, M. (2017). Unravelling the effects of Science Parks on the innovation performance of NTBFs. The Journal of Technology Transfer. https://doi.org/10.1007/ s10961-017-9559-y.

Ratinho, T., \& Henriques, E. (2010). The role of science parks and business incubators in converging countries: Evidence from Portugal. Technovation, 30(4), 278-290. 
Salvador, E. (2011). Are science parks and incubators good "brand names" for spin-offs? The case study of Turin. The Journal of Technology Transfer, 36(2), 203-232.

Siegel, D. S., Westhead, P., \& Wright, M. (2003). Assessing the impact of university science parks on research productivity: Exploratory firm-level evidence from the United Kingdom. International Journal of Industrial Organization, 21(9), 1357-1369.

Squicciarini, M. (2008). Science Parks' tenants versus out-of-Park firms: Who innovates more? A duration model. Journal of Technology Transfer, 33(1), 45-71.

Squicciarini, M. (2009). Science parks: Seedbeds of innovation? A duration analysis of firms' patenting activity. Small Business Economics, 32(2), 169-190.

Storey, D. J., \& Tether, B. S. (1998). New technology-based firms in the European Union: An introduction. Research Policy, 26(9), 933-946.

Svensson, P., Klofsten, M., \& Etzkowitz, H. (2012). An entrepreneurial university strategy for renewing a declining industrial city: The Norrköping way. European Planning Studies, 20(4), 505-525.

Vásquez-Urriago, Á. R., Barge-Gil, A., Rico, A. M., \& Paraskevopoulou, E. (2014). The impact of science and technology parks on firms' product innovation: Empirical evidence from Spain. Journal of Evolutionary Economics, 24(4), 835-873.

Vedovello, C. (1997). Science parks and university-industry interaction: Geographical proximity between the agents as a driving force. Technovation, 17(9), 491-502.

VINNOVA. (2018). Swedish governmental agency for innovation systems. Available at http://www.vinno va.se/en. Accessed 1 February 2018.

WAINOVA. (2009). Wainova Atlas of innovation: Science/technology/research parks and business incubators in the world. Cheshire: Ten Alps Publishing.

Westhead, P., \& Batstone, S. (1998). Independent technology-based firms: The perceived benefits of a science park location. Urban Studies, 35(12), 2197-2219.

Westhead, P., \& Batstone, S. (1999). Perceived benefits of a managed science park location. Entrepreneurship \& Regional Development: An International Journal, 11(2), 129-154.

Westhead, P., \& Storey, D. J. (1995). Links between higher-education institutions and high-technology firms. Omega-International Journal of Management Science, 23(4), 345-360.

Yang, C. H., Motohashi, K., \& Chen, J. R. (2009). Are new technology-based firms located on science parks really more innovative? Evidence from Taiwan. Research Policy, 38(1), 77-85.

Yin, R. K. (2009). Case study research: Design and methods (Vol. 5). London: Sage. 